\title{
STRATEGY OPTIONS TO IMPROVE GROSS MARGIN IN MIXED CROP-LIVESTOCK FARMING SYSTEM IN SOHAG GOVERNORATE, EGYPT
}

\author{
S.M. Alsheikh ${ }^{1}$, A. Elnahas ${ }^{2}$, Salah Galal $^{3}$, E. Mousa ${ }^{4}$ and M. \\ Elshennawy
}

1-Animal and Poultry Breeding Department, Desert Research Center, 2- Animal Production Department, Faculty of Agriculture, Sohag University 3- Animal Production Department, Faculty of Agriculture, Ain Sham University,4- Animal Production \& Breeding Department, College of Agriculture \& Veterinary Medicine, Qassim University, KSA, 5- Sustainable Development Department, Environmental Studies and Research Institute, Sadat Branch, Menofia University

\section{SUMMARY}

The objectives of this study were to describe the mixed crop-livestock production system among small farms in Sohag governorate, South Egypt and to investigate options for its improvement. Three districts were randomly selected out of the eleven districts of the governorate, Jirjah, Sohag and Akhmim. Data on 420 farmers $(35$ farmers within 4 villages within 3 districts) were collected during 2004-2005. A linear programming LP model with four scenarios was tested to maximize gross margin (GM), the first assumes free choice among all studied variables of crops and livestock (base run (LP1)). While, the second scenario (LP2) had a constraint on cropping pattern to meet farmer's needs of basic food and feed crops and assuming free choice of number of each different animal types (local cattle, crossbred cattle buffalo, sheep and goat). The third scenario (LP3) assumed free choice of cropping pattern and had a constraint to the number of each studied animal type. The fourth scenario (LP4) had the cultivated area distributed equally on different crops and had a constraint to the number of each animal types. Results suggested that, as compared to actual situation, GM was improved by about $48 \%$ to $105 \%$ in LP1; $19 \%$ to $67 \%$ in LP2 and $30 \%$ to $72 \%$ in LP3 and $-0.3 \%$ to $33 \%$ in LP4 in different distracts. As compared to LP1, GM in LP2 and LP3 decreased by about 29 to $38 \%$ and $18 \%$ to $33 \%$, respectively. GM in LP3 increased by about $5 \%$ to $11 \%$ as compared to LP2. In addition, GM in LP4 decreased by about $48 \%$ to $72 \%$ as compared to LP1. It was concluded that small ruminants were more profitable than large ruminants within crop-livestock production system in Sohag governorate. Both land and available cash resources are limiting constrains for LP model but not labor.

Keywords: Linear programming, Gross margin, Sheep, Goat

\section{INTRODUCTION}

In many developing countries, the distribution of livestock ownership suggests that livestock farming is especially important for the poor and landless who have insufficient land to support their families. Egypt is one of the most densely populated countries in the Mediterranean, African and Near East region. Located in the more

Issued by The Egyptian Society of Animal Production 
arid region of the world, the arable land does not exceed 3.4 millions hectares and more than $95 \%$ of crop lands are irrigated with the Nile. The average land size does not exceed 1 ha per farm and the number of farms increased from 1 to 3.7 millions from 1950 to 2000. Sohag governorate, located in South Egypt, that encompasses Aswan, Sohag, Qena, Red Sea and Luxor City. Agriculture is the governorate's basic economic activity where cultivated areas cover 315.5 thousand feddans $(1$ feddan $=$ $4200 \mathrm{sq} \mathrm{m}$ ) (ICLDU, 2006). The main production system in Sohag is the mixed croplivestock production. This work aimed at investigating different options of input combinations to improve crop-small ruminant production subsystem in Sohag within the crop-livestock production.

\section{MATERIALS AND METHODS}

\section{Data Collection and Coefficients:}

Sohag governorate is in the middle of the South Egypt between 26" 36 " $26 \mathrm{~N}$ latitudes and 31" 47" 80 E longitudes. The governorate comprises eight districts on the western side of the River Nile and three districts on the eastern side (Figure 1). Three districts were randomly selected for this study, Jirjah, Sohag (in the western side of the River Nile) and Akhmim (in the eastern side of the River Nile). Within each district four villages were randomly selected and thirty five farmers within each village were randomly chosen (total number of farmers $=420$ ).

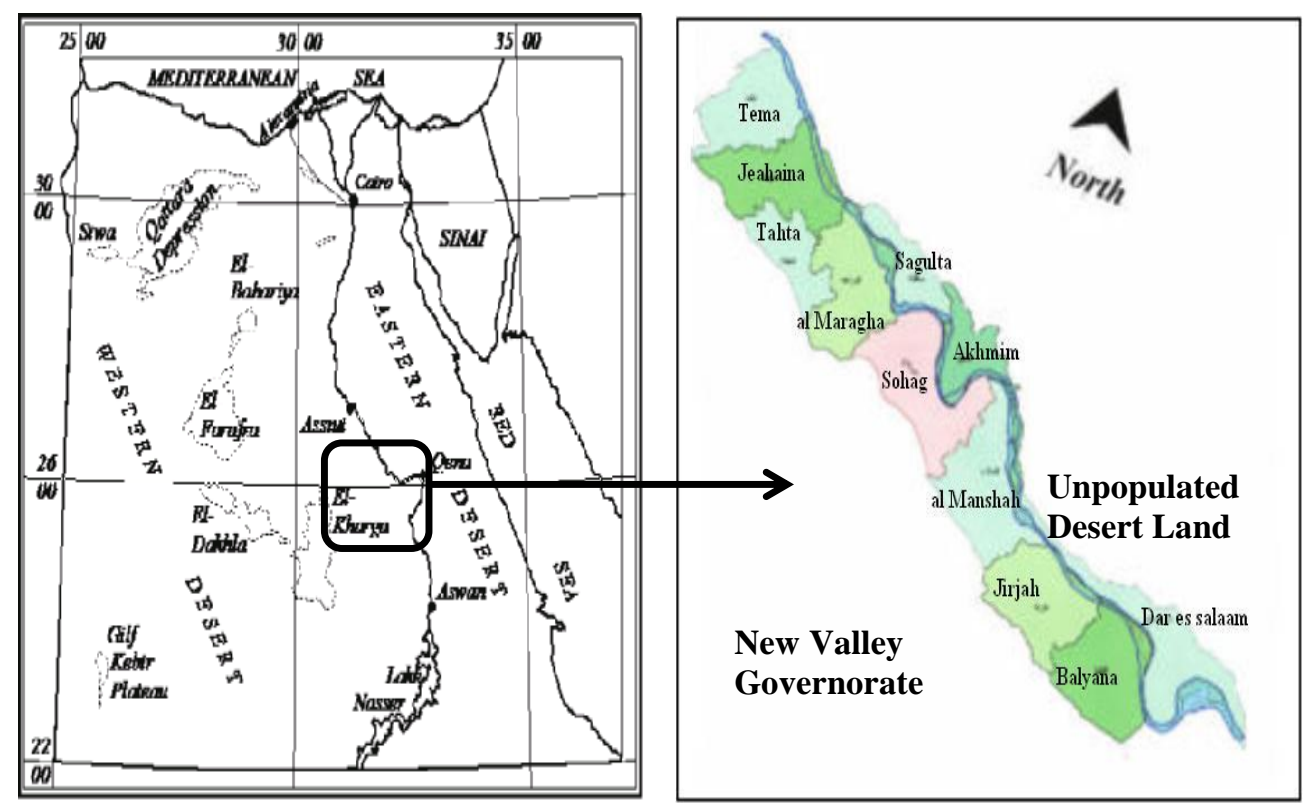

$0 \quad 100 \quad 200 \quad 300 \quad 400 \mathrm{~mm}$

Figure 1. Map of Egypt and map of Sohag governorate

Data were collected during 13 months from August 2004 to September 2005. 
Information was collected through a field survey using structured questionnaire to identify available resources (Table 1), as follows:

- general information on village, district and date of visit;

- socio-economic features of the farmer and his family;

- family members contribution in cultivation and animal production activities;

- farm size and main field crops;

- flock and herd size for different livestock species; and

- management systems of small ruminant flocks/herd.

Variables included in this study were area cultivated each with wheat (Triticum Sp.), berseem (Trifolium alexandrinum) and faba bean (Vicia faba) as winter crops and maize (Zea mays), sorghum (Sorghum bicolor), millet (Pennisetum typhoides) and darawa (fodder maize) (Zea mays) as summer crops. Livestock variables were number of local cattle, crossbred cattle, buffalo, sheep, goats and animal units (AU).

Table 1. Description of available resources in the three different studied districts

\begin{tabular}{llll}
\hline Item & Akhmim & Jirjah & Sohag \\
\hline $\begin{array}{l}\text { Sample size } \\
\text { Resources }\end{array}$ & 140 & 140 & 140 \\
Average farm size (feddan)* & & & \\
Average family size (person) & 1.58 & 1.59 & 1.87 \\
Annual labor used (p/d) & 6.12 & 4.99 & 6.36 \\
$\quad$ Winter & & & \\
$\quad$ Summer & 516 & 417 & 511 \\
Cropping pattern (feddan) & 516 & 417 & 511 \\
Winter Wheat & & & \\
$\quad$ Berseem & 0.66 & 0.84 & 0.93 \\
$\quad$ Faba bean & 0.85 & 0.62 & 0.85 \\
$\quad 0.07$ & 0.12 & 0.09 \\
$\quad$ Sorghum & 0.47 & 0.50 & 0.64 \\
$\quad$ Millet & 0.26 & 0.51 & 0.42 \\
$\quad$ Green fodder (darawa) & 0.71 & 0.13 & 0.72 \\
$\quad 0.14$ & 0.12 & 0.09 \\
Local cattle (AU) & & & \\
Crossbred cattle (AU) & 0.36 & 0.34 & 0.31 \\
Buffalo (AU) & 0.0 & 0.15 & 0.11 \\
Sheep (EE) & 1.13 & 1.04 & 1.01 \\
Goat (DE) & 14.32 & 10.97 & 12.70 \\
Total (AU) & 6.15 & 5.45 & 6.41 \\
Livestock & 4.97 & 4.32 & 4.68 \\
\hline
\end{tabular}

$*$ feddan $=4200 \mathrm{~m}^{2}, \mathrm{p} / \mathrm{d}=$ person per day, $\mathrm{AU}=$ animal unit, $\mathrm{EE}=$ ewe equivalent $=1.89$ lamb, $\mathrm{DE}=$ doe equivalent $1.89 \mathrm{kid}$. Animal unit $=5.9$ ewe or doe, $\mathrm{AU}=11.1$ lamb or kid, $\mathrm{AU}$ $=3.3$ calves $\mathrm{AU}=0.89$ buffalo and $\mathrm{AU}=1$ mature cattle (Barnard and Nix, 1993)

Mathematical Linear Programming (LP) Model.

Studies by Alsheikh et al. (2002) and Alsheikh et al. (2007) showed that land and livestock are the most determinant variables in crop-livestock production system in Egypt. One LP model was used with four modified scenarios tested utilizing land, livestock, labor and amount of available cash resources (ACR) using General 
Algebra Modeling Systems (GAMS, 2000). Modification was tried only on land and livestock constrains. While, labor and ACR constancies are the same in the different four studies scenarios.

Base Run Scenario (LP1). Assuming free choice of crop and livestock studied variables to maximize the gross margin $(\mathrm{GM})$, where,

Objective function Maximize $(\mathrm{GM})=\sum_{i=1}^{12} \mathrm{a}_{\mathrm{i}} \mathrm{x}_{\mathrm{i}}$,

where,

$\mathrm{a}_{\mathrm{i}}$ is GM for each variable of $\mathrm{x}_{\mathrm{i}}, \mathrm{x}_{\mathrm{i}}$ are area in feddans cultivated with wheat $\left(\mathrm{x}_{1}\right)$, berseem $\left(\mathrm{x}_{2}\right)$, faba bean $\left(\mathrm{x}_{3}\right)$, maize $\left(\mathrm{x}_{4}\right)$, sorghum $\left(\mathrm{x}_{5}\right)$, millet $\left(\mathrm{x}_{6}\right)$ and green fodder $\left(\mathrm{x}_{7}\right)$ (darawa), number of local cattle $\left(\mathrm{x}_{8}\right)$, crossbred cattle $\left(\mathrm{x}_{9}\right)$, with the constraints: buffalo $\left(\mathrm{x}_{10}\right)$, sheep $\left(\mathrm{x}_{11}\right)$ and goat $\left(\mathrm{x}_{12}\right)$.

Land: Winter $\quad \mathrm{x}_{1}+\mathrm{x}_{2}+\mathrm{x}_{3}=$ average farm size (feddan)

Summer $\mathrm{x}_{4}+\mathrm{x}_{5}+\mathrm{x}_{6}+\mathrm{x}_{7}=$ average farm size (feddan)

Livestock: $\quad \mathrm{x}_{8}+\mathrm{x}_{9}+\mathrm{x}_{10}+\mathrm{x}_{11}+\mathrm{x}_{12} \leq$ livestock respective numbers,

$$
\begin{aligned}
& \text { Labor: } \quad \sum_{i=j=1}^{12} \mathrm{c}_{\mathrm{j}} \mathrm{x}_{\mathrm{i}} \leq \mathrm{b} \\
& \text { where, } \\
& \mathrm{c}_{\mathrm{j}} \text { is labor (person per day) requirement, } \\
& \mathrm{b} \text { is the total family labor and } \mathrm{x}_{\mathrm{i}} \text { as before; } \\
& \text { and available cash resources (ACR), } \quad \sum_{i=j=1}^{12} \mathrm{~d}_{\mathrm{j}} \mathrm{x}_{\mathrm{i}} \leq \mathrm{m} \text {, } \\
& \text { where, } \\
& \mathrm{d}_{\mathrm{j}} \text { is variable cost for each variable, } \\
& \mathrm{m} \text { is } \mathrm{ACR} \text {, and } \mathrm{x}_{\mathrm{i}} \text { as before. }
\end{aligned}
$$

\section{Diversity of cultivated crops scenario (LP2):}

In this scenario the cultivated area was distributed equally on different crops and assuming free choice of livestock species to maximize GM, where the

$$
\begin{aligned}
& \text { Objective function was Maximize }(\mathrm{GM})=\sum_{i=1}^{12} \mathrm{a}_{\mathrm{i}} \mathrm{x}_{\mathrm{i}}, \\
& \text { where, } \\
& \qquad \mathrm{a}_{\mathrm{i}} \text { and } \mathrm{x}_{\mathrm{i}} \text { are as defined before, } \\
& \begin{array}{c}
\mathrm{x}_{1}=1 / 3 \text { farm size } \\
\text { Lith constraints: } \\
\mathrm{x}_{2}=1 / 3 \text { farm size } \\
\mathrm{x}_{3}=1 / 3 \text { farm size } \\
\mathrm{x}_{1}+\mathrm{x}_{2}+\mathrm{x}_{3} \leq \text { average farm size }
\end{array}
\end{aligned}
$$

Summer $\quad \mathrm{x}_{4}=1 / 4$ farm size 


$$
\begin{aligned}
& \mathrm{x}_{5}=1 / 4 \text { farm size } \\
& \mathrm{x}_{6}=1 / 4 \text { farm size } \\
& \mathrm{x}_{7}=1 / 4 \text { farm size } \\
& \mathrm{x}_{4}+\mathrm{x}_{5}+\mathrm{x}_{6}+\mathrm{x}_{7} \leq \text { average farm size. }
\end{aligned}
$$

Livestock, labor and ACR are the same as in LP1.

\section{Modified Flock Structure Scenario (LP3):}

In this scenario a free choice of cultivated crops was assumed and livestock production was constrained with at least one animal unit (AU) of local cattle, crossbred cattle or buffalo in addition to at least one ewe equivalent (EE) of sheep and doe equivalent (DE) of goat to maximize GM.

Objective function:

$$
\operatorname{Maximize}(\mathrm{GM})=\sum_{i=1}^{12} \mathrm{a}_{\mathrm{i}} \mathrm{x}_{\mathrm{i}}
$$

where,

with constraints:

$$
\mathrm{a}_{\mathrm{i}} \text { and } \mathrm{x}_{\mathrm{i}} \text { are as defined before. }
$$

Land: Winter $\mathrm{x}_{1}+\mathrm{x}_{2}+\mathrm{x}_{3} \leq$ average farm size (feddan)

$$
\text { Summer } \mathrm{x}_{4}+\mathrm{x}_{5}+\mathrm{x}_{6}+\mathrm{x}_{7} \leq \text { average farm size (feddan) }
$$

Livestock:

$$
\begin{aligned}
& \mathrm{x}_{8} \geq 1 \text { AU of local cattle } \\
& \mathrm{x}_{9} \geq 1 \text { AU of cross bred cattle } \\
& \mathrm{x}_{10} \geq 1 \text { AU of buffalo } \\
& \mathrm{x}_{11} \geq 1 \text { ewe equivalent } \\
& \mathrm{x}_{12} \geq 1 \text { doe equivalent }
\end{aligned}
$$

Labor and ACR are the same as LP1.

\section{Real Scenario (LP4):}

The constraints of this scenario were designed to simulate the real situation as appearing in the actual situation. In this scenario the cultivated area was distributed equally on different crops while livestock was constrained with at least one animal unit (AU) of local cattle, crossbred cattle or buffalo in addition to at least one ewe equivalent $(\mathrm{EE})$ of sheep and one doe equivalent (DE) of goat to maximize GM.

Objective function:

$$
\operatorname{Maximize}(G M)=\sum_{i=1}^{12} a_{i} x_{i},
$$

where,

Constraints:

$$
\mathrm{a}_{\mathrm{i}} \text { and } \mathrm{xi} \text { are as defined before. }
$$

Land: Winter, $x_{1}=1 / 3$ farm size

$\mathrm{x}_{2}=1 / 3$ farm size

$\mathrm{x}_{3}=1 / 3$ farm size

$\mathrm{x}_{1}+\mathrm{x}_{2}+\mathrm{x}_{3} \leq$ average farm size

Summer, $x_{4}=1 / 4$ farm size

$\mathrm{x}_{5}=1 / 4$ farm size

$\mathrm{x}_{6}=1 / 4$ farm size 


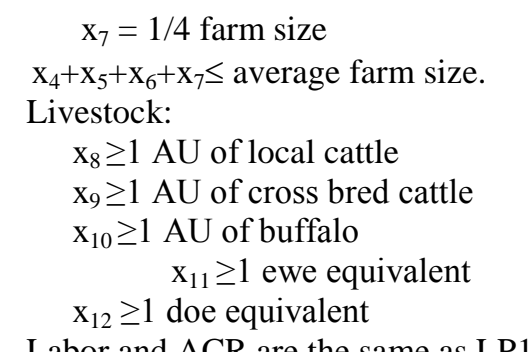

\section{RESULTS AND DISCUSSION}

Financial Analysis:

Table 2 shows GM for each crop per feddan and livestock activity calculated from collected data. The GM of all the studied variables was positive in the three districts except for local cattle and buffalo in Jirjah, LE -228 and LE -141, respectively. This could be due to that farmers in Jirjah cultivated only 0.25 feddan of green fodder (darawa plus millet) in summer (Table 1). This cultivated area is too small for feeding animals where farmers kept an average of $4.32 \mathrm{AU}$ (Table 1), thus farmers depended on concentrate feed which has a high monetary value.

Table 2. Gross output (GO), variable cost (VC), gross margin (GM) and available cash resources (ACR) in Egyptian pound (LE) per feddan

\begin{tabular}{|c|c|c|c|c|c|c|c|c|c|}
\hline \multirow[t]{2}{*}{ Item } & \multicolumn{3}{|c|}{ Akhmim } & \multicolumn{3}{|c|}{ Jirjah } & \multicolumn{3}{|c|}{ Sohag } \\
\hline & GO & $\mathrm{VC}$ & GM & GO & $\mathrm{VC}$ & GM & GO & $\mathrm{VC}$ & GM \\
\hline \multicolumn{10}{|l|}{ Winter crops } \\
\hline Wheat & 3581 & 881 & 2700 & 3485 & 851 & 2635 & 3518 & 852 & 2666 \\
\hline Berseem & 3171 & 272 & 2899 & 3082 & 264 & 2819 & 3075 & 270 & 2805 \\
\hline Faba bean & 2210 & 531 & 1679 & 2226 & 559 & 1667 & 2093 & 521 & 1572 \\
\hline \multicolumn{10}{|l|}{ Summer crops } \\
\hline Maize & 2527 & 1045 & 1482 & 2677 & 1051 & 1626 & 2540 & 1052 & 1488 \\
\hline Sorghum & 2232 & 900 & 1332 & 2234 & 886 & 1348 & 2249 & 902 & 1347 \\
\hline Millet & 3724 & 565 & 3159 & 3836 & 546 & 3291 & 3527 & 553 & 2974 \\
\hline Darawa & 3735 & 544 & 3141 & 3892 & 574 & 3319 & 2979 & 524 & 2455 \\
\hline \multicolumn{10}{|c|}{ Livestock activities } \\
\hline Local cattle & 1650 & 1464 & 186 & 1252 & 1467 & -228 & 1602 & 1388 & 213 \\
\hline Cross- cattle & & & & 1968 & 1837 & 132 & 1883 & 1479 & 404 \\
\hline Buffalo cow & 1298 & 1081 & 216 & 976 & 1095 & -141 & 1162 & 979 & 183 \\
\hline Adult ewe & 166 & 91 & 75 & 187 & 132 & 55 & 183 & 110 & 73 \\
\hline Adult doe & 103 & 71 & 32 & 91 & 68 & 24 & 87 & 62 & 25 \\
\hline ACR & & 7406 & & & 9335 & & & 8691 & \\
\hline
\end{tabular}

Values rounded to the nearest integer.

Base Run (LP1):

The results of LP1 for the three districts are shown in Table 3. In order that farmers get the maximum GM, the output suggests that, they should go for sheep and cultivate all their farm area with berseem in winter, in the three districts. While in summer, they should cultivate all area with green fodder (darawa), in Akhmim and Jirjah, and with millet in Sohag. Also, they should keep 67, 60 and 65 ewe 
equivalents in Akhmim, Jirjah and Sohag, respectively, with no other livestock. Moreover, if farmers decided to cultivate wheat and faba bean in winter (Table 3 ) in Akhmim their production cost would reduce by LE 700 and LE 1433 per feddan, respectively. While, in summer cultivating maize, sorghum and millet would reduce production cost by LE 2121, LE 2152 and LE 49 per feddan, respectively. GM in LP1 was higher than that in the actual situation by about $51 \%, 105 \%$ and $48 \%$, in Akhmim, Jirjah and Sohag, respectively. This improvement of GM is due to directing the available cash resources to variables with the highest GM. Return per feddan in LP1 was higher than that in actual situation by about $51 \%, 114 \%$ and $48 \%$ in Akhmim, Jirjah and Sohag, respectively. These results have the same trend as the results obtained by Alsheikh et al. (2002 and 2007). The contribution of livestock to GM in LP1 came from sheep only. This could be due to that sheep have low variable cost. Also, goats have the lowest opportunity cost in the three studied districts. These results agree with Younis (1998) in that small ruminants could be more profitable than large ruminants in crop-livestock production system in South Egypt.

\section{Diversity of cultivated crops (LP2):}

This scenario was designed to avert market risk due to cultivating only one type of crop and to satisfy farmers basic crop needs. The optimal LP2 for Akhmim, Jirjah and Sohag is shown in Table 3. To get maximum GM for farmers they should raise 58,54 and 56 ewe equivalents in the three districts, respectively plus the restricted cultivated area within each district. In this scenario, the land constraint led to increased both GM and RPF by about $22 \%, 67 \%$ and $19 \%$ than actual situation and to decreased GM and RPF by about $29 \%, 40 \%$ and $29 \%$ than the base run (LP1) in Akhmim, Jirjah and Sohag, respectively. These results could be due to farmers by transferring their ACR to the cultivation of crops to satisfy their needs, they have less money to keep sheep. These results support the finding of Bhatia and Ganwar (1981) that, farmers have different type of thinking other than just maximizing their farm income. Also, Abdulkadri and Ajibefun (1998) suggested that farmers could have objective(s) other than profit maximization like family consumption and diversification of crops to avert market risk.

\section{Modified flock structure (LP3):}

In this scenario the LP programming was modified as free choice of cropping pattern in winter and summer, while livestock was constrained with at least one animal unit from local cattle, crossbred cattle and buffalo plus one ewe equivalent and one doe equivalent to maximize GM. The optimal LP3 for the three districts are shown in Table 3. The cropping pattern in LP3 was the same as suggested from LP1 along with raising one AU of local cattle, one AU of buffalo, $31 \mathrm{EE}$ and $10 \mathrm{DE}$ in Akhmim. While in Jirjah farmers have to raise one AU each from local cattle, crossbred cattle and buffalo plus $22 \mathrm{EE}$ and $10 \mathrm{DE}$ to get maximum GM. Also, in Sohag the farmers should keep the same AU each from large ruminants plus $24 \mathrm{EE}$ and $10 \mathrm{DE}$. These results led GM in LP3 being higher than that in actual situation by about $31 \%, 72 \%$ and $30 \%$, less than the value obtained in LP1 by $20 \%, 33 \%$ and $18 \%$ and higher than the value obtained in LP2 by $9 \%, 5 \%$ and $11 \%$ in Akhmim, Jirjah and Sohag, respectively. This is due to the constraints on raising livestock which has less GM and keeping less number of small ruminants. 


\section{The real scenario (LP4):}

The optimal LP4 for the three districts are shown in Table 3. When modifying the LP model constraints to simulate the real situation, the output shows that farmer should have one AU each of local cattle, crossbred cattle, buffalo and 10 doe equivalents in Akhmim Jirjah and Sohag, respectively, plus keeping 22, 16 and 16 ewe equivalents to get maximum GM. Constraining cultivated crops and keeping all animal genotypes led to GM to be less than the value obtained in LP1 by $49 \%, 72 \%$ and $48 \%$ in Akhmim, Jirjah and Sohag, respectively. While in Akhmim and Jirjah GM was higher than that in actual situation by about 2\% and 33\% and in Sohag was less than that in actual situation by about $0.33 \%$, respectively. Moreover, the return per feddan was changing by $3 \%, 25 \%$ and $-0.03 \%$ in Akhmi, Jirjah, and Sohag, respectively compared with actual situation. This could be due to the land constrain, which led to directing the available cash resources to cultivation and raising large ruminants, which have less GM than small ruminants thus allowing less available cash resources to keep ewe equivalents.

\section{CONCLUSIONS}

The present linear programming model with the four scenarios showed that sheep followed by goats are more profitable than large ruminants within the crop-livestock production system in South Egypt. Land, livestock and available cash resources are limiting constrains but not labor.

\section{REFERENCES}

Abdulkadri, A. O. and I. A. Ajibefun, 1998. Developing alternative farm plants for cropping system decision making, Agriculture System, 4: 431-442.

Alsheikh, S.M, A.M. Ahmed, H. Mansour and E.S.E. Galal, 2002. Improving crop/livestock production system in a newly reclaimed land in Egypt. Egyptian J. Anim. Prod. 39:147-160.

Alsheikh, S.M, S. Galal, Reham M. N. Rashwan and Samira A. Arafa, 2007. Evaluation of crop-dairy production system in Nile Delta. Egypt. Egyptian J. Anim. Prod., (2007) 44(1):71-81

Barnard, C.S. and J.S. Nix, 1993. Farm Planning and Control (2 $2^{\text {nd }}$ Ed.). Cambridge Press, Cambridge, UK.

Bhatia, H.C. and A.C. Gangwar, 1981. Optimum combination of crops and livestock enterprises on small farms in Karnal district. The Indian Journal of Dairy Science 34: 60-66.

GAMS, 2000. General Algebra Modeling system software, version. 2.5, GAMS Development Corporation, 1217 Potomac St, N W Washington, DC 20007, USA.

ICLDU, 2006. Information Centers of Local Development Unit. Sohag governorate administration office, Sohag, Egypt.

Younis A.A., 1998. Small ruminant production systems in Egypt. Egyptian J. Anim. Prod. Suppl. Issue, 35: 128-144. 


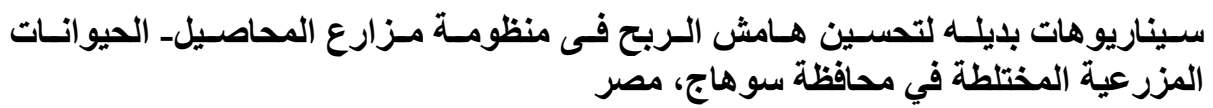

سمير الثيخ'، أحمد النحاس '، صلاح جلال"، عماد موسى،، محمد الثناوى5

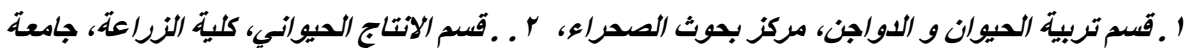

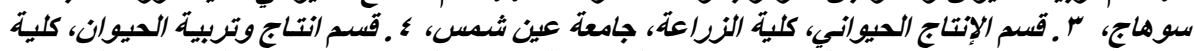

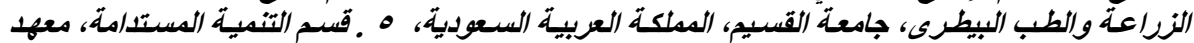
اللدراسات والبحوث البيئة، فرع مدينة السادات، جامعة المنوفية

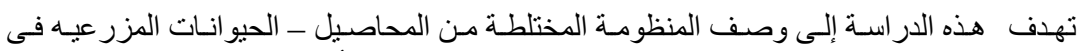

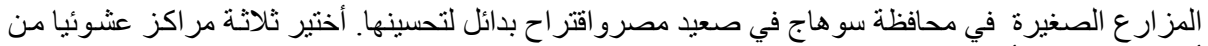

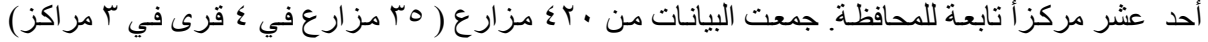

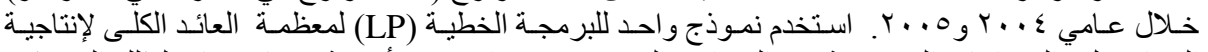

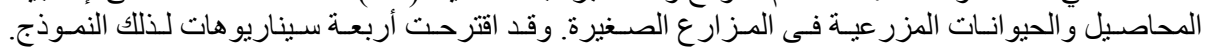

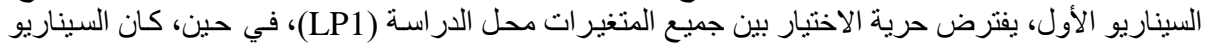

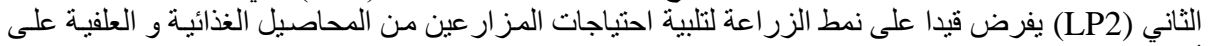

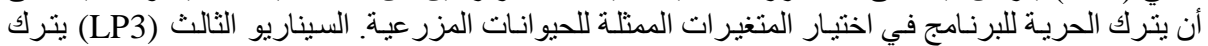

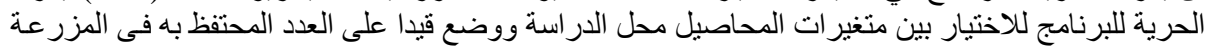

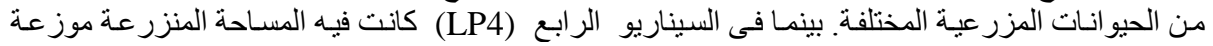

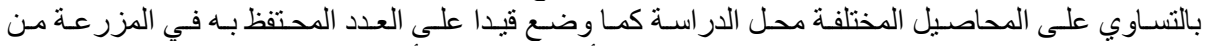

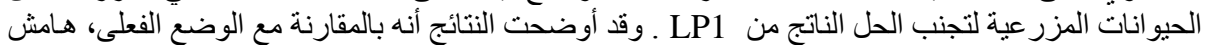

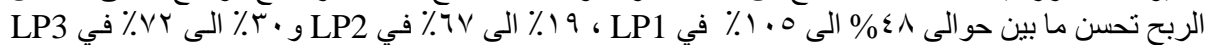

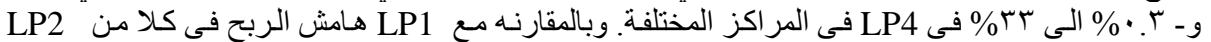

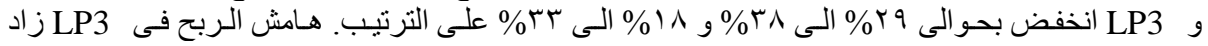

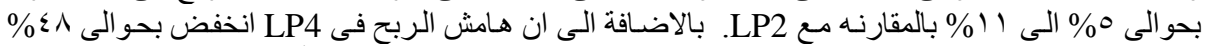

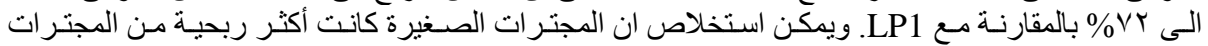

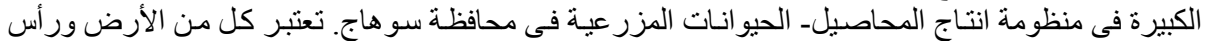
المال المتاج من العو امل المحدة لنموذج البرمجة الخطية بينما لم تكن العمالة كذلك 
Egyptian J. Anim. Prod. (2011) 48(2):147-156

Table 3. Linear programming LP1, LP2, LP3 and LP4 output of the three studies districts, diversity of cultivated crops

\begin{tabular}{|c|c|c|c|c|c|c|c|c|c|c|c|c|c|c|c|c|c|c|c|c|c|c|c|c|}
\hline \multirow{2}{*}{ Item } & \multicolumn{8}{|c|}{ Akhmim } & \multicolumn{8}{|c|}{ Jirjah } & \multicolumn{8}{|c|}{ Sohag } \\
\hline & AS & LP1 & $\mathrm{OC}$ & LP2 & $\mathrm{OC}$ & LP3 & OC & $\overline{\mathrm{LP} 4}$ & AS & LP1 & $\mathrm{OC}$ & LP2 & $\mathrm{OC}$ & LP3 & $\mathrm{OC}$ & LP4 & $\mathrm{AS}$ & LP1 & $\mathrm{OC}$ & LP2 & $\mathrm{OC}$ & LP3 & $\mathrm{OC}$ & LP4 \\
\hline \multicolumn{25}{|c|}{ Cropping pattern (feddan) } \\
\hline \multicolumn{25}{|c|}{ Winter } \\
\hline Wheat & 0.66 & 0 & 700 & 0.53 & 0 & 0 & 700 & 0.53 & 0.84 & 0 & 427 & 0.84 & 0.53 & 0 & 428 & 0.53 & 0.93 & 0 & 524 & 0.63 & 0 & 0 & 524 & 0.62 \\
\hline Berseem & 0.85 & 1.58 & 0 & 0.53 & 0 & 1.58 & 0 & 0.53 & 0.62 & 1.59 & 0 & 0.62 & 0.53 & 1.59 & 0 & 0.53 & 0.85 & 1.87 & 0 & 0.63 & 0 & 1.87 & 0 & 0.62 \\
\hline Faba bean & 0.07 & 0 & 1433 & 0.53 & 0 & 0 & 1433 & 0.53 & 0.12 & 0 & 1273 & 0.12 & 0.53 & 0 & 1273 & 0.53 & 0.09 & 0 & 1399 & 0.63 & 0 & 0 & 1399 & 0.62 \\
\hline \multicolumn{25}{|l|}{ Summer } \\
\hline :Maize & 0.47 & 0 & 2121 & 0.4 & 0 & 0 & 2121 & 0.4 & 0.50 & 0 & 1890 & 0.50 & 0.4 & 0 & 1890 & 0.4 & 0.64 & 0 & 1817 & 0.47 & 0 & 0 & 1817 & 0.46 \\
\hline Sorghum & 0.26 & 0 & 2152 & 0.4 & 0 & 0 & 2152 & 0.4 & 0.51 & 0 & 2100 & 0.51 & 0.4 & 0 & 2100 & 0.4 & 0.42 & 0 & 1858 & 0.47 & 0 & 0 & 1858 & 0.46 \\
\hline Millet & 0.71 & 0 & 49 & 0.4 & 0 & 0 & 49 & 0.4 & 0.13 & 0 & 16 & 0.13 & 0.4 & 0 & 16 & 0.4 & 0.72 & 1.87 & 0 & 0.47 & 0 & 1.87 & 0 & 0.46 \\
\hline Darawa & 0.14 & 1.58 & 0 & 0.4 & 0 & 1.58 & 0 & 0.4 & 0.12 & 1.59 & 0 & 0.12 & 0.4 & 1.59 & 0 & 0.4 & 0.09 & 0 & 499 & 0.47 & 0 & 0 & 499 & 0.46 \\
\hline \multicolumn{25}{|l|}{ Livestock } \\
\hline L-cattle (AU) & 0.36 & 0 & 1020 & 0 & 1202 & 1 & 0 & 1 & 0.34 & 0 & 834 & 0.34 & 0 & 1 & 0 & 1 & 0.31 & 0 & 707 & 0 & 707 & 1 & 0 & 1 \\
\hline C-cattle (AU) & 0 & 0 & 0 & 0 & 0 & 0 & 0 & 0 & 0.15 & 0 & 627 & 0.15 & 0 & 1 & 0 & 1 & 0.11 & 0 & 577 & 0 & 589 & 1 & 0 & 1 \\
\hline Buffalo (AU) & 1.13 & 0 & 673 & 0 & 673 & 1 & 0 & 1 & 1.04 & 0 & 594 & 1.04 & 0 & 1 & 0 & 1 & 1.01 & 0 & 466 & 0 & 466 & 1 & 0 & 1 \\
\hline Sheep (EE) & 14.3 & 67 & 0 & 58 & 0 & 31 & 0 & 22 & 10.9 & 60 & 0 & 10.9 & 54 & 22 & 0 & 16 & 12.70 & 65 & 0 & 56 & 0 & 24 & 0 & 16 \\
\hline Goat (DE) & 6.15 & 0 & 26 & 0 & 26 & 10 & 0 & 10 & 5.45 & 0 & 4 & 5.45 & & 10 & 0 & 10 & 6.41 & 0 & 16 & 0 & 16 & 10 & 0 & 10 \\
\hline \multicolumn{25}{|c|}{ Land (feddan) } \\
\hline Winter & 1.58 & 1.58 & 0 & 1.58 & 0 & 1.58 & 0 & 1.58 & 1.59 & 1.59 & 0 & 1.59 & 0 & 1.59 & 0 & 1.59 & 1.87 & 1.87 & 0 & 1.87 & 0 & 1.87 & 0 & 1.87 \\
\hline Summer & 1.58 & 1.58 & 0 & 1.58 & 0 & 1.58 & 0 & 1.58 & 1.59 & 1.59 & 0 & 1.59 & 0 & 1.59 & 0 & 1.59 & 1.87 & 1.87 & 0 & 1.87 & 0 & 1.87 & 0 & 1.87 \\
\hline \multicolumn{25}{|c|}{ Labor $(\mathrm{p} / \mathrm{d})$} \\
\hline Winter & 516 & 516 & 0 & 516 & 0 & 516 & 0 & 516 & 417 & 417 & 0 & 417 & 0 & 417 & 0 & 417 & 511 & 511 & 0 & 511 & 0 & 511 & 0 & 511 \\
\hline Summer & 516 & 516 & 0 & 516 & 0 & 516 & 0 & 516 & 417 & 714 & 0 & 714 & 0 & 417 & 0 & 417 & 511 & 511 & 0 & 511 & 0 & 511 & 0 & 511 \\
\hline $\mathrm{ACR}(\mathrm{LE} / \mathrm{F})$ & 7406 & & & & & & & & 9335 & & & & & & & & 8691 & & & & & & & \\
\hline GM (LE) & 9674 & 14663 & & 11884 & & 1270 & & 9924 & 6348 & 1306 & & 10616 & & 10968 & & 8494 & 10457 & 1555 & & 1245 & & 13640 & & 10422 \\
\hline
\end{tabular}

Issued by The Egyptian Society of Animal Production 
